\title{
2 First records and potential palaeoecological significance 3 of Dianella (Xanthorrhoeaceae), an extinct representative 4 of the native flora of Rapa Nui (Easter Island)
}

Núria Cañellas-Boltà $\cdot$ Valentí Rull •

Alberto Sáez $\cdot$ Matthew Prebble $\cdot$ Olga Margalef

7 Received: 21 June 2013/Accepted: 9 January 2014

8 (C) Springer-Verlag Berlin Heidelberg 2014

Communicated by A. E. Bjune.

Electronic supplementary material The online version of this article (doi:10.1007/s00334-014-0432-8) contains supplementary material, which is available to authorized users.

\section{N. Cañellas-Boltà $(\square) \cdot$ A. Sáez}

Department of Stratigraphy, Paleontology \& Marine

Geosciences, Universitat de Barcelona, Martí Franquéss/n,

08028 Barcelona, Spain

e-mail: nuriacatcb@gmail.com

\section{N. Cañellas-Boltà · V. Rull}

Palynology \& Paleoecology Lab, Botanic Institute of Barcelona (IBB-CSIC-ICUB), Passeig del Migdia s/n, 08038 Barcelona, Spain

\section{Prebble}

Archaeology and Natural History, School of Culture History and Languages, College of Asia and the Pacific, The Australian National University, Canberra, ACT 0200, Australia

\section{O. Margalef}

Institute of Earth Sciences Jaume Almera (ICTJA-CSIC), Lluís Soler Sabarís s/n, 08028 Barcelona, Spain been linked to the existence of favorable paleoenvironmental conditions (peatland rather than the present-day lacustrine environment) during the early to mid Holocene. This finding contributes new knowledge about indigenous plant diversity on Easter Island and reinforces the usefulness of further macrofossil and pollen analyses to identify native species on Easter Island and elsewhere.

Keywords Dianella $\cdot$ Easter Island · Native plant . Holocene $\cdot$ Palaeoecology $\cdot$ Local extinction

\section{Introduction}

Easter Island is a tiny isolated island in the South Pacific Ocean, famed as an example of environmental degradation due to human overexploitation of natural resources (Flenley and Bahn 2003; Diamond 2005; Rull et al. 2010a). Currently the island is covered nearly entirely by grasslands, but palaeoecological studies have suggested the occurrence of former forested vegetation dominated by palms and the presence of several other tree and shrub species (e.g. Flenley et al. 1991; Dumont et al. 1998; Azizi and Flenley 2008; Mann et al. 2008). Climatic changes and human activities during the last two millennia have largely modified the island's landscape and vegetation (Flenley et al. 1991; Flenley 1993a; Azizi and Flenley 2008; Mann et al. 2008; Butler and Flenley 2010; Cañellas-Boltà et al. 2013). A consequence has been the local extinction of a number of native species from the island. Among the most emblematic cases are the disappearance of the probably endemic palm Paschalococos disperta, a supposed close relative of the extant Jubaea chilensis, distributed throughout the coastland central areas of Chile, and the disappearance of Sophora toromiro, an endemic legume

\begin{tabular}{lll} 
Journal : Large 334 & Dispatch : 19-1-2014 & Pages : 8 \\
Article No. : $\mathbf{4 3 2}$ & $\square$ LE & $\square$ TYPESET \\
MS Code : VHAA-D-13-00041 & $\boldsymbol{\sim}_{\mathrm{CP}}$ & $\checkmark$ DISK \\
\hline
\end{tabular}


surviving only as a cultivated shrub on the island and in some botanical gardens elsewhere (Flenley et al. 1991; Zizka 1991; Maunder et al. 2000).

In addition to the disappearance of representatives of the original flora, numerous exotic species, such as Eucalyptus spp. and Melinis minutiflora, have been introduced in recent times, and some of these, such as Psidium guajava and Crotalaria grahamiana, have become invasive. Currently, the flora of Easter Island is composed of approximately 200 established vascular plant species $(\sim 180$ flowering plants and $\sim 17$ ferns), of which 30 flowering species are considered native (Zizka 1991; Flenley 1993b). In a recent revision, Dubois et al. (2013) only recognized 36 native and extant vascular plants (including ferns). Among the many species that have been introduced, only $\sim 15$ are considered to have been brought by the original Polynesian settlers in the last millennia, while the rest are modern introductions occurring after European contact in the 18th century (Flenley et al. 1991; Flenley 1993b; Dubois et al. 2013). Moreover, most of the native plants are currently considered to be endangered due to human activities and are very scarce and restricted to particular habitats (Zizka 1991; Dubois et al. 2013).

Because of these striking vegetation changes, including local extinctions and introductions, occurring after human occupation, the native flora of the island remains poorly characterized. It has been speculated that the native flora could have been poor due to the small size and the extreme isolation of the island (Skottsberg 1956; Zizka 1991). Descriptions provided by some of the early European visitors to the island supply some information on the flora, but few collections were made and many of the descriptions were imprecise (Zizka 1991; Hunt 2007). This information has been complemented with archaeological studies of microfossils-pollen, phytoliths, and starch grains (e.g., Cummings 1998; Horrocks and Wozniak 2008) —as well as studies of macrofossils and wood charcoal (Orliac and Orliac 1998; Orliac 2000), which have provided more details on the flora following human settlement. However, direct evidence of the flora and its changes before human arrival is only provided by palaeoecological records, largely based on palynological surveys of lake sediment cores (e.g., Flenley et al. 1991; Azizi and Flenley 2008; Mann et al. 2008; Butler and Flenley 2010) and a few macrofossil records (Mann et al. 2008; Cañellas-Boltà et al. 2012). Here, we report the existence of a previously unobserved plant (Dianella sp.) that was part of the native Easter Island flora during the early to middle Holocene, long before human arrival, and which is now extinct. This species has been identified on the basis of its characteristic pollen and seeds, found in a sediment core from Lake Raraku. The ecological preferences and the potential palaeoecological usefulness of Dianella are discussed.

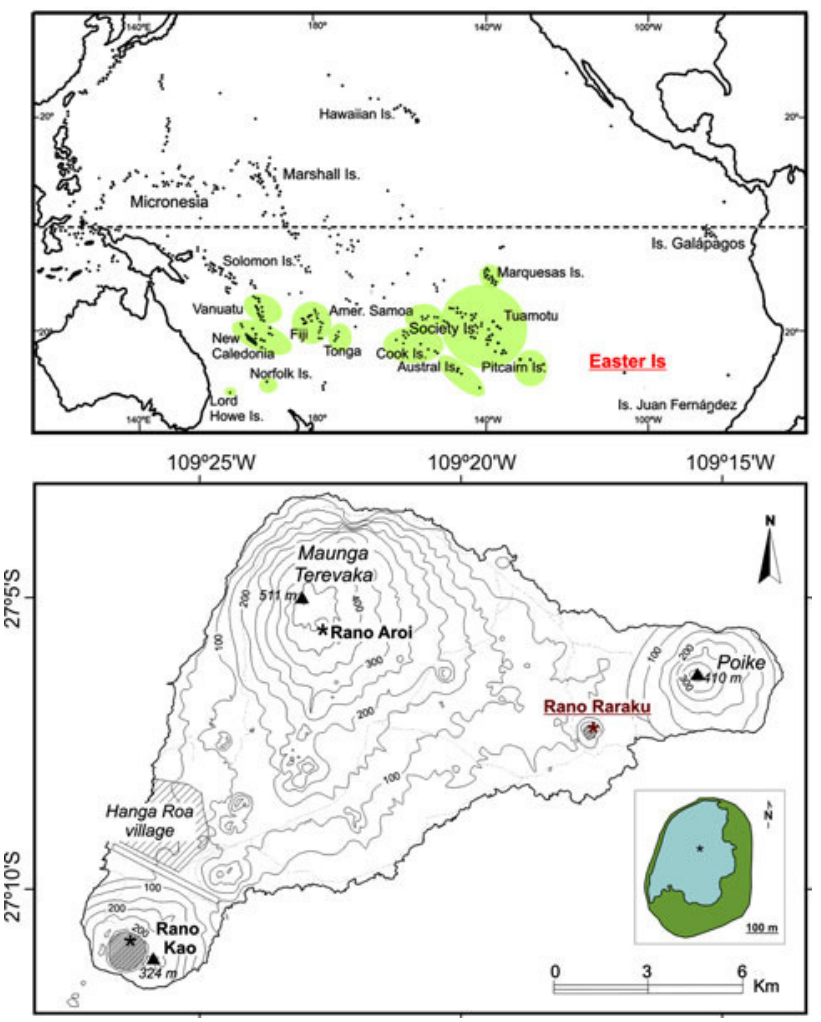

Fig. 1 Above map of current distribution of Dianella intermedial adenanthera in the Pacific Islands (shaded) (see "Discussion" section for further information). Note that with the presence on Easter Island, the occupation area of the plant extended over practically all the tropical and subtropical fringe of the South Pacific Ocean. Map modified from Elix and McCarthy (2008). Below a map of the island showing the location of Lake Raraku (Rano Raraku). In the box, position of the coring point in the lake is shown

\section{Study site}

Easter Island is a subtropical volcanic island located in the South Pacific Ocean $\left(27^{\circ} 7^{\prime} \mathrm{S}, 109^{\circ} 22^{\prime} \mathrm{W}\right.$; Fig. 1) approximately $3,700 \mathrm{~km}$ west of the Chilean coast and 2,030 km east of the nearest inhabited island (Pitcairn). The island has a roughly triangular shape, with three main volcanic cones, situated one in each corner, and an area of only $\sim 164 \mathrm{~km}^{2}$. The topography is characterized by the existence of these three main volcanoes, nearly 70 vents and the rolling surfaces of the lava flows between them. The highest point is the summit of the Terevaka volcano $(511 \mathrm{~m})$. No permanent surface streams are present because of the high permeability of volcanic rocks (Herrera and Custodio 2008). At present, only the bottoms of the craters of Rano Raraku and Rano Kau (now occupied by lakes), and Rano Aroi (now filled by a fen) permanently contain closed freshwater bodies. Currently, the island is mostly $(90 \%)$ covered by grasslands, with a few tree plantations, shrub areas and pioneer vegetation (Etienne

\begin{tabular}{|l|lll|}
\hline Journal : Large 334 & Dispatch : 19-1-2014 & Pages : 8 \\
Article No. : 432 & $\square$ LE & $\square$ TYPESET \\
MS Code : VHAA-D-13-00041 & $\sim_{\text {CP }}$ & $\checkmark$ DISK \\
\hline
\end{tabular}


et al. 1982). The climate is subtropical, with an average annual temperature of $21{ }^{\circ} \mathrm{C}$ and a range of average monthly temperatures between 16 and $18{ }^{\circ} \mathrm{C}$ (July-September) and $24-26{ }^{\circ} \mathrm{C}$ (January-March) (Mann et al. 2008; Sáez et al. 2009). The total annual precipitation is highly variable, ranging between 500 and 2,000 mm, with long alternating dry and humid periods (Horrocks and Wozniak 2008). The studied core was retrieved from Lake Raraku, a small $\left(0.11 \mathrm{~km}^{2}\right)$ shallow (2-3 m deep) freshwater lake (Sáez et al. 2009), situated at an altitude of $75 \mathrm{~m}$ inside a volcanic crater more than 300,000 years old (Baker et al. 1974). The lake is topographically and hydrologically closed and disconnected from the island's main groundwater, and is fed solely by precipitation (Herrera and Custodio 2008). Today, the lake has a flat bottom and is surrounded by a littoral belt dominated by Scirpus californicus, which also forms large floating mat patches.

\section{Materials and methods}

This work is part of a palaeoecological study based on macrofossil and pollen analyses carried out on a sedimentary composite sequence $19 \mathrm{~m}$ in total length drilled in Lake Raraku. This sequence is mainly composed by peaty and lacustrine muddy sediments. The coring methods and a detailed stratigraphic description of the core are described in Sáez et al. (2009). Samples for the macrofossil analysis were processed following standard protocols (Birks 2001). A volume between 20 and $50 \mathrm{~cm}^{3}$ of sediment per sample was analyzed. Dispersion of the sediment was facilitated by the addition of a small amount of $\mathrm{KOH}(10 \%$; more details are given in Cañellas-Boltà et al. 2012). Samples for pollen analysis were processed according to standard laboratory protocols for pollen analysis, slightly modified (Rull et al. $2010 b$ ), including $\mathrm{KOH}, \mathrm{HCl}$ and $\mathrm{HF}$ digestions and acetolysis. Lycopodium tablets (batch 177745, Lund University, Sweden) were added to each sample before chemical processing as an exotic marker and used to calculate the pollen concentration. The microscopic pollen slides were mounted in silicone oil. The pollen and macrofossil data were plotted using psimpoll 4.26 (Bennett 2002). The chronological framework used in this work was established in previous studies based on radiocarbon dates on pollenenriched extracts and Scirpus sp. fragments (Sáez et al. 2009; Cañellas-Boltà et al. 2012)

\section{Results}

Seeds and pollen of Dianella sp. (Fig. 2) dating from the early to mid Holocene have been identified in peaty sediments in the Raraku core (Fig. 3; Supplementary Data in ESM 1-3). The seeds were previously reported as unidentified macrofossils, using the code IBB-111 (Cañellas-Boltà et al. 2012). The pollen study of the sequence is still in progress. Both macrofossil and pollen records show the consistent presence of this taxon from $\sim 7$ to $\sim 1.5 \mathrm{~m}$ downcore, with a continuous occurrence and greater abundance from 6 to $1.5 \mathrm{~m}$ (Fig. 3). According to the chronological framework established in previous studies (Sáez et al. 2009; Cañellas-Boltà et al. 2012), this corresponds to $\sim 9.4-5.5 \mathrm{cal}$. kyr B.P., i.e., several thousand years before human occupation of the island. This plant has not been identified in previous palaeoecological and archaeological works, so this finding represents the first evidence of its presence on the island. The pollen assemblage corresponding to the interval with Dianella sp. is
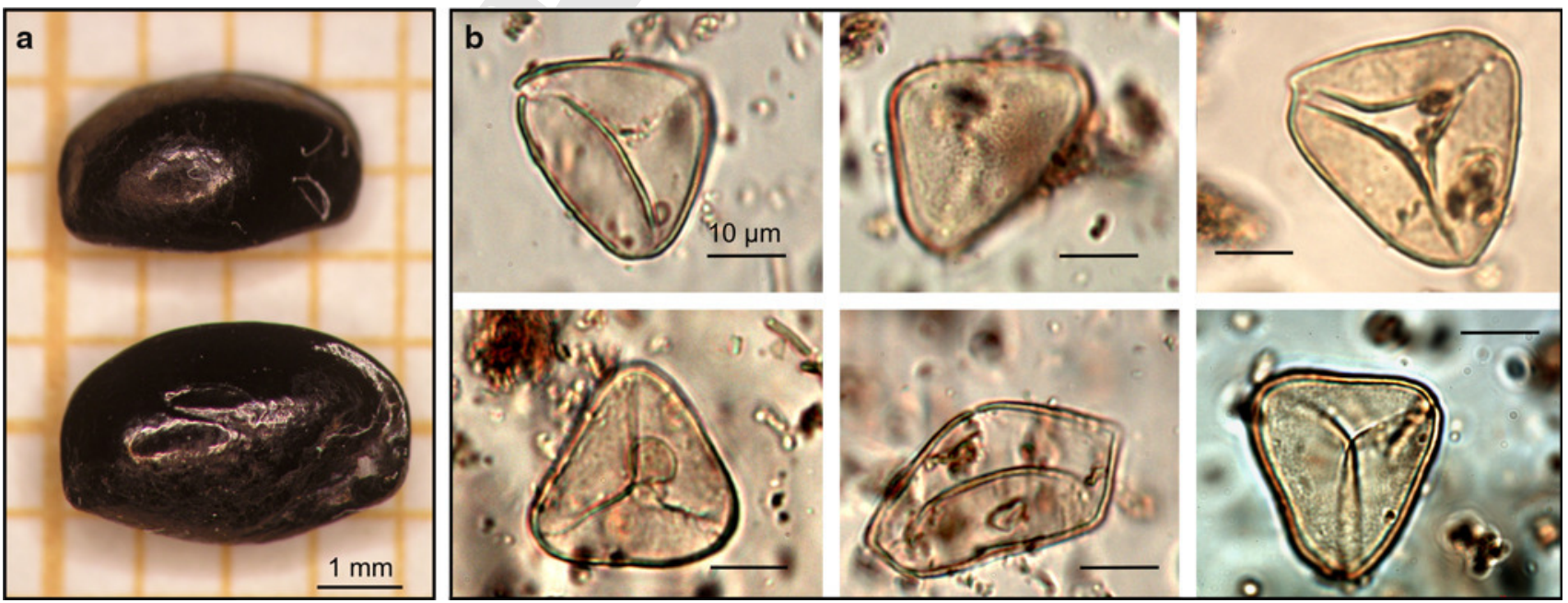

Fig. 2 Seeds (a) and pollen (b) of Dianella sp. observed in Lake Raraku sediments. See more photographs in the ESM 2, 3

\begin{tabular}{|l|lll|}
\hline Journal : Large 334 & Dispatch : 19-1-2014 & Pages : 8 \\
Article No. : 432 & $\square$ LE & $\square$ TYPESET \\
& MS Code : VHAA-D-13-00041 & $\checkmark$ CP & $\checkmark$ DISK \\
\hline
\end{tabular}




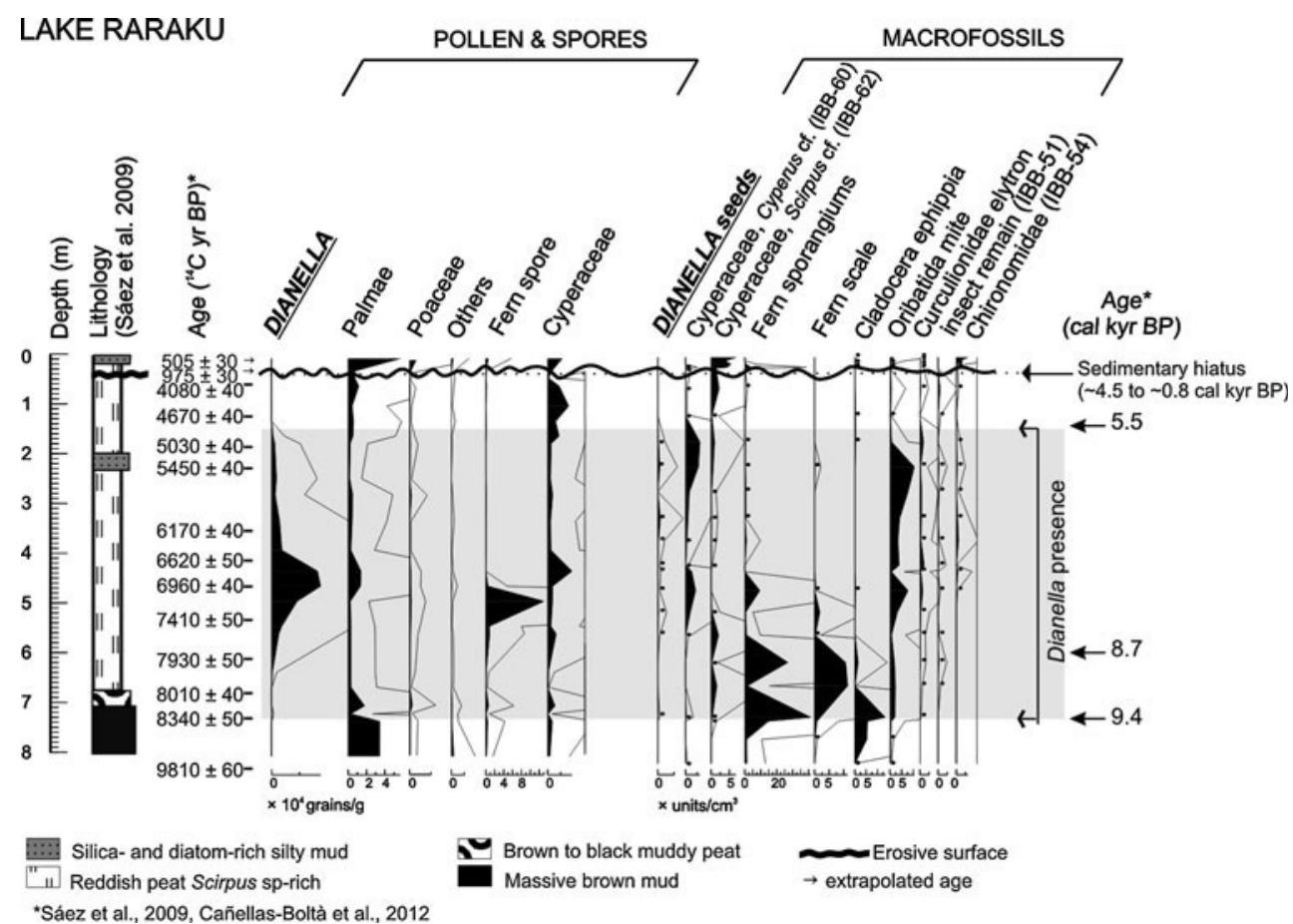

Fig. 3 Diagram of main pollen, spores and macrofossils in the first $8 \mathrm{~m}$ of depth of a core recovered from Lake Raraku, showing the presence of Dianella pollen and seeds at depths from 1.5 to $7 \mathrm{~cm}$. Other includes pollen observed in very low concentration, such as
Sophora, Triumfetta, Asteraceae and others. Lithology and ${ }^{14} \mathrm{C}$ radiocarbon dates are indicated on the left, and calibrated ages on the right. The period of time when Dianella is found is indicated in shaded grey
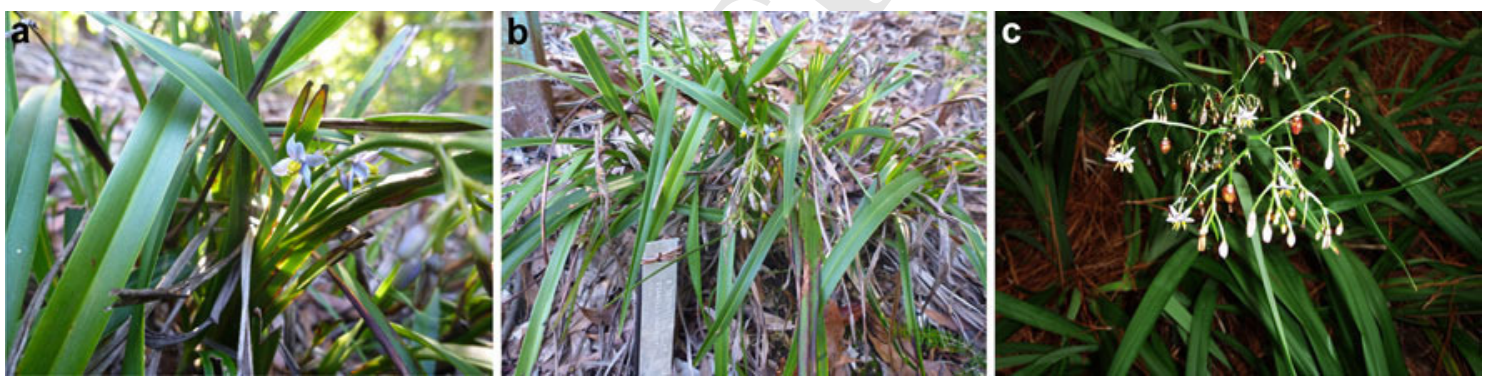

Fig. 4 Pictures of Dianella intermedia/adenathera (a, $\mathbf{b}$ from Norfolk Is. and $\mathbf{c}$ from Ravaivae). Photos by Matthew Prebble

characterized by the presence of palms, Cyperaceae, Poaceae and fern spores. The main macrofossils found together with the Dianella sp. seeds are Cyperaceae seeds and fern remains (sporangia and scales), and oribatid mites and insect fragments in great abundance (Coleoptera, Chironomidae, etc.) (Cañellas-Boltà et al. 2012).

\section{Discussion}

\section{Taxonomic identity and biogeography}

Dianella is a genus of evergreen rhizomatous herbs or subshrubs broadly known by the common name flax lilies
(Fig. 4). As presently understood, Dianella is a monocot genus of flowering plants belonging to the Xanthorrhoeaceae, within the Asparagales, with 41 species recognized (Chase et al. 2009; APG III 2009; WCSP 2012). The genus is widely distributed in the Pacific Islands, from southeastern Africa, through Southeast Asia to Hawaii, Australia, New Zealand and Bolivia (Moore and Edgar 1970; Smith 1979; Elliot and Jones 1984; George 1987, 1994; WCSP 2012) (Supplementary Data in ESM 4).

Both pollen and seeds of Dianella from the Raraku sediments are morphologically similar to $D$. intermedia and $D$. adenanthera (Fig. 5). The taxonomy of the genus is not fully resolved, and it is not yet clear whether these names are synonyms or correspond to two different species with

\begin{tabular}{|l|lll|}
\hline & Journal : Large 334 & Dispatch : 19-1-2014 & Pages : 8 \\
Article No. : 432 & $\square_{\text {LE }}$ & $\square$ \\
MS Code : VHAA-D-13-00041 & $\checkmark_{\mathrm{CP}}^{\text {TYPESET }}$ \\
\hline
\end{tabular}



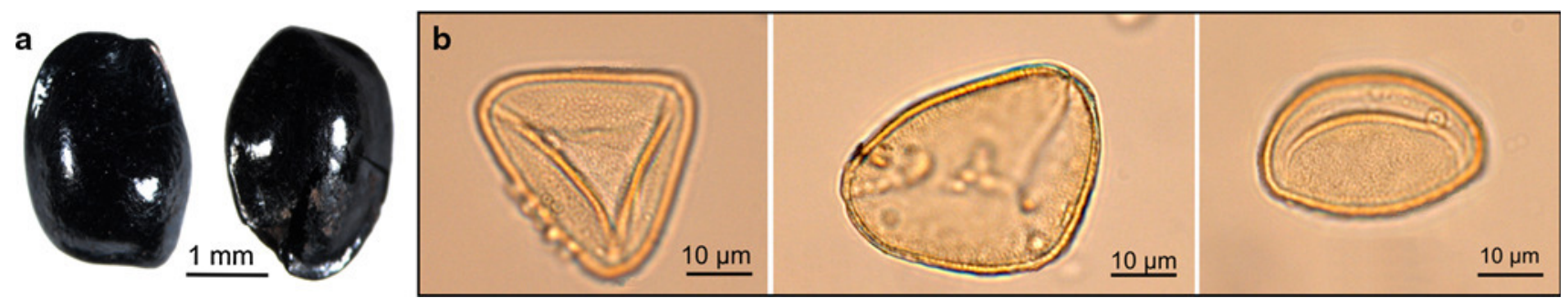

Fig. 5 Pictures of seeds (a) and pollen (b) of Dianella intermedia/adenanthera. Plant material from Allan Herbarium (CHR). Photos by Matthew Prebble

different distribution areas. For the purpose of this study, the name $D$. cf. intermedia/adenanthera was adopted. According to WCSP (2012), D. intermedia is endemic to the Norfolk Islands, whereas $D$. adenanthera is widely distributed in many of the Pacific Islands, such as Fiji, New Caledonia, Tonga, Vanuatu, and the Cook, Marquesas, Pitcairn, Society, Tuamotu, and Tubuai Islands (WCSP 2012) (ESM-4). This taxonomic and biogeographic distinction is not shared by other authors. The name $D$. intermedia has been used by some in a broader sense (George 1994) in the Pitcairn, Henderson, French Polynesian and other Pacific Islands (e.g., Smith 1979; George 1987; Paulay and Spencer 1989; Waldren et al. 1995; Florence et al. 2007; Franklin et al. 2008; Butaud 2010). A full revision of this genus is needed to clarify its taxonomy (George 1994).

However some differences in seed size and pollen morphology suggest that it might be another species, maybe an endemic plant. Nevertheless we do not have enough data to properly support this, and therefore we prefer to follow a conservative approach and have called it $D$. cf. intermedial adenanthera. Another species of the genus present in the central and eastern Pacific Ocean is D. sandwicensis, which has a disjunct distribution that includes New Caledonia, the Marquesas Islands and the Hawaiian Islands (WCSP 2012). Nevertheless, its seeds are smaller and more obovate. Other current members of the genus (e.g., D. carolinensis, D. saffordiana) are located far from Easter Island, most of them with distributions restricted to certain islands, archipelagos or regions, although some others have wider distributions in the Pacific (e.g., D. revoluta, D. ensifolia, D. javanica) (ESM-4).

The results shown here, together with other past records from islands where the species is currently absent, such as Rimatara (French Polynesia) (Prebble and Wilmshurst 2009; Prebble, unpublished data), enhance the past distribution area of $D$. cf. intermedialadenanthera across the Pacific.

Ecological preferences and potential paleoenvironmental usefulness

Extant Dianella species usually form dense terrestrial 1-2 m high clumps, tufts or spreading colonies that grow in many different habitats: grasslands, shrublands, moist forests, dry woodlands, grassy wetlands, coastal dunes, rocky areas, swamps and mires, etc. (e.g., Moore and Edgar 1970; Elliot and Jones 1984; Wardle 1991; George 1994; Hunter and Bell 2007; Franklin et al. 2008). Propagation can be by seeds, most probably through birds eating the fruit, but vegetative propagation by clump division is very common (Elliot and Jones 1984).

For the fossil Dianella recorded in this study, the lithological, geochemical and biological features of the sediments where its pollen and seeds were found can provide environmental insights into its habitat preferences. Although at present the bottom of the Raraku crater is occupied by a shallow lake, changes in the lake level and palaeoenvironment between lacustrine and mire conditions have been described since the Last Glacial Period (Sáez et al. 2009). The stratigraphic interval where Dianella is found in the Raraku sequence ( $\sim 7$ to $\sim 1.5 \mathrm{~m}$ ) corresponds to a sedimentary unit composed of reddish-brown massive and banded peaty deposits (Sáez et al. 2009). These deposits consist of abundant grass and sedge macroremains (notably sedge seeds), together with invertebrate faunal remains such as oribatid mites, Coleoptera Curculionidae and other animal fragments, which have been interpreted as indicative of mire conditions (Sáez et al. 2009; Cañellas-Boltà et al. 2012). The high concentration of Dianella pollen observed and the presence of numerous seeds suggest a highly localized and abundant presence of the plant, most likely growing directly on the palaeopeatland inside the Raraku crater. Therefore, the results suggest that the pollen and seeds of Dianella in the record are associated with mire conditions (water saturated but not flooded), and hence, they are potentially useful as palaeoecological indicators of these conditions. This should be tested in further palaeoecological analysis. Although Dianella sp. are not species restricted to wetland habitats, some species have been observed in ombrotrophic bogs, swamps and other mires (e.g. Wardle 1991; Bell et al. 2012). These wetlands are characterized by being fed only by precipitation and by commonly being nutrient-poor and acidic, which may be similar to the past conditions of the Raraku palaeo-mire. Furthermore, macrofossil and pollen records suggest a plant community growing at that time in the

$\begin{array}{lll}\text { Journal : Large } 334 & \text { Dispatch : 19-1-2014 } & \text { Pages : } 8 \\ \text { Article No. : } \mathbf{4 3 2} & \square \text { LE } & \square \text { TYPESET } \\ \text { MS Code : VHAA-D-13-00041 } & \boldsymbol{V}_{\mathrm{CP}} & \checkmark \text { DISK }\end{array}$


crater dominated by Dianella sp. and Cyperaceae, with some Poaceae, as well as abundant ferns during the initial phases of this period (Fig. 3). The presence of palm pollen suggests the likely presence of palm stands surrounding the mire.

This palaeohabitat at the Raraku site would have been established after a lake level drop at the beginning of the Holocene ( $\sim 9.4$ cal. kyr B.P.) that transformed the late Pleistocene Raraku lake phase (characterized by muddy sedimentation) into a mire (Sáez et al. 2009). Both the progressive sedimentary infilling of the basin and possibly warmer and drier climate conditions would have favored the existence and development of such a mire environment during the early to mid Holocene period (Sáez et al. 2009; Cañellas-Boltà et al. 2012). Some palaeoclimatic records suggest that warmer and drier climatic conditions such as these occurred during the early to mid Holocene at similar latitudes along the west coast of central Chile (e.g., Jenny et al. 2002; Valero-Garcés et al. 2005; Maldonado and Villagrán 2006; Sáez et al. 2007; Kaiser et al. 2008). Previous palynological research on Easter Island has indicated that overall warm and moist conditions prevailed during this period (Flenley et al. 1991; Butler and Flenley 2010), although the possibility of some dry phases was also suggested (Flenley el al. 1991). However, a clear climatic scenario for this period cannot be drawn from these studies due to poor data, large sedimentary gaps, and the difficulty of establishing a sound chronological framework (Flenley et al. 1991; Flenley 1996).

\section{Dianella extirpation at the Raraku site}

Currently, Dianella is not found on Easter Island, either in natural or in cultivated form; therefore, it can be declared extirpated on the island. Climatic and ecological changes are the most likely causes for the growth and demise of Dianella sp. observed at Raraku. The disappearance of Dianella sp. from the pollen record coincides with an increase in Cyperaceae pollen (Fig. 3) and a shift in the Cyperaceae seed record, with the replacement of Cyperustype seeds by Scirpus-type seeds (Fig. 3). Other noteworthy changes observed are the decrease in oribatid mite and insect remains and the appearance of some cladoceran ephippia (Fig. 3). These changes, combined with an increase in magnetic susceptibility (ms) and decreases in $\mathrm{C} / \mathrm{N}$ and $\delta^{13} \mathrm{C}$ values (Sáez et al. 2009; Cañellas-Boltà et al. 2012) suggest a likely progressive rise of the water level in the Raraku mire (Sáez et al. 2009), as has also been observed in similar records (Ancour et al. 1999; Hong et al. 2001). A high water table may have favored the development of more aquatic plants such as Scirpus sp. (which is now dominant in the lake littoral areas) and prevented the development of Dianella sp. and other plants typical of non-flooded habitats. This is consistent with some regional palaeoclimatic records of similar latitude in central Chile that suggest increased humidity approximately $5.7-4 \mathrm{cal}$. kyr B.P. (e.g., Jenny et al. 2002; Valero-Garcés et al. 2005; Maldonado and Villagrán 2006; Sáez et al. 2007; Kaiser et al. 2008), most likely as a result of an increase in the frequency of El Niño events (Kaiser et al. 2008).

The disappearance of Dianella from the Raraku record approximately $5.4 \mathrm{cal}$. kyr B.P. does not necessarily imply its coincident extinction from the island. Many Dianella species appear to be very resistant plants that can survive in extreme environments, growing in many habitats, including rocky outcrops and cliffs, as observed in populations from other Pacific islands. Moreover, the Raraku record does not capture the entire diversity of the island. Therefore, the continuity of Dianella in other Easter Island locations cannot be dismissed. Our data do not permit elucidation of the final decline of this plant on the island as a whole. Further palaeoecological research conducted on sediments from other localities, such as the Rano Aroi fen (Margalef et al. 2013) and the Rano Kau lake, will hopefully shed more light in this issue.

\section{Conclusion and final remarks}

The dramatic transformations of the landscape of Easter Island during the last millennia have resulted in numerous plant introductions and local extinctions. These changes, together with the lack of knowledge of the flora just before human arrival, as well as the few and imprecise reports of the first European expeditions, make it difficult to elucidate the native plant diversity on the island. Furthermore, determining whether a species is native or introduced (by Polynesian settlers or by the first Europeans or by the ensuing colonizers) is often complicated. This study provides an example of the usefulness of combined palynological and plant macrofossil studies of core sediments in identifying native plants and past plant distributions because such combined analyses provide unequivocal evidence of past plant occurrence. A new plant has been identified as native to Easter Island through the identification of seeds and pollen in sediments from a core recovered from a lake. This plant, Dianella sp., most likely $D$. cf. intermedia/adenanthera, was present during the early to mid Holocene (from 9.4 to 5.4 cal. kyr B.P.) in the Raraku crater in what was previously a peaty environment. Its presence in the sedimentary record of the Raraku basin infill is linked to the environmental conditions (mainly of the water table) that configured a mire environment in which the plant appeared to grow. Therefore, the presence of pollen and seeds of Dianella may represent potential palaeoecological indicators of such conditions. The 
disappearance of this plant is most likely linked to an increase in the water level in the Raraku crater but does not necessarily represent its total extinction from the island because the crater does not represent the complete diversity of the island. Studies such as this support the existence of greater diversity on the island than previously thought. Further palaeoecological research on sediments from other localities in Easter Island and other Pacific Island, would help to trace the history of Dianella.

Acknowledgments This research was funded by the Spanish Ministry of Science and Education, through the projects LAVOLTER (CGL2004-00683/BTE), GEOBILA (CGL2007-60932/BTE) and CONSOLIDER GRACCIE (CSD2007-00067) and an undergraduate Grant (BES-2008-002938 to N. Cañellas-Boltà). We are grateful to CONAF (Chile) and the Riroroko family for the facilities provided on Easter Island. We also thank Hilary H. Birks and Teresa Garnatje for their assistance during the work and Juan José Pueyo for his help with SEM photographs.

\section{References}

Ancour A-M, Bonnefille R, Hillaire-Marcel C (1999) Sources and accumulation rates of organic carbon in an equatorial peat bog (Burundi, East Africa) during the Holocene: carbon isotope constraints. Palaeogeogr Palaeoclimatol Palaeoecol 150:179-189

APG III (2009) An update of the Angiosperm Phylogeny Group classification for the orders and families of flowering plants: APG III. Bot J Linn Soc 161:105-121

Azizi G, Flenley JR (2008) The last glacial maximum climatic conditions on Easter Island. Quat Int 184:166-176

Baker PE, Buckley F, Holland JG (1974) Petrology and geochemistry of Easter Island. Contrib Mineral Petrol 44:85-100

Bell DM, Hunter JT, Montgomery L (2012) Ephemeral wetlands of the Pilliga Outwash, northwest NSW. Cunninghamia 12:181-190

Bennett KD (2002) Documentation for psimpoll 4.10 and pscomb 1.03 , C programs for plotting pollen diagrams and analysing pollen data. Uppsala University, Uppsala

Birks HH (2001) Plant macrofossils. In: Smol JP, Birks HJB, Last WM (eds) Tracking environmental change using lake sediments, vol 3. Kluwer, Dordrecht, pp 49-74

Butaud J-F (2010) Gambier. Guide floristique. Direction De l'Environnement. Government of French Polynesia, Papeete http:// www.environnement.pf/spip.php?article125

Butler KR, Flenley J (2010) The Rano Kau 2 pollen diagram: paleoecology revealed. Rapa Nui J 24:5-10

Cañellas-Boltà N, Rull V, Sáez A, Margalef O, Giralt S, Pueyo JJ, Birks HH, Birks HJB, Pla-Rabes S (2012) Macrofossils in Raraku Lake (Easter Island) integrated with sedimentary and geochemical records: towards a paleoecological synthesis. Quat Sci Rev 34:113-126

Cañellas-Boltà N, Rull V, Sáez A, Margalef O, Bao R, Pla-Rabes S, Blaauw M, Valero-Garcés B, Giralt S (2013) Vegetation changes and human settlement of Easter Island during the last millennia: a multiproxy study of the Lake Raraku sediments. Quat Sci Rev 72:36-48

Chase MW, Reveal JL, Fay MF (2009) A subfamilial classification for the expanded asparagalean families Amaryllidaceae, Asparagaceae and Xanthorrhoeaceae. Bot J Linn Soc 161:132-136
Cummings LS (1998) A review of recent pollen and phytolith studies from various contexts on Easter Island. In: Stevenson CM, Lee G, Morin FJ (eds) Easter Island in Pacific context, South Seas symposium: proceedings of the fourth international conference on Easter Island and East Polynesia, Los Osos, pp 100-106

Diamond J (2005) Collapse. How societies choose to fail or survive. Allen Lane, London

Dubois A, Lenne P, Nahoe E, Rauch M (2013) Plantas de Rapa Nui. Guía Ilustrada de la Flora de Interés Ecológico y Patrimonial. Umanga mo te Natura, CONAF. ONF International, Santiago

Dumont HJ, Cocquyt C, Fontugne M, Arnold M, Reyss JL, Bloemendal J, Oldfield F, Steenbergen LM, Korthals HJ, Zeeb B (1998) The end of moai quarrying and its effects on Lake Rano Raraku, Easter Island. J Paleolimnol 20:409-422

Elix JA, McCarthy PM (2008) Checklist of Pacific Island Lichens. Australian Biological Resources Study, Canberra. Version 21 August 2008. http://www.anbg.gov.au/abrs/lichenlist/Pacific_ introduction.html

Elliot WR, Jones DL (1984) Encyclopaedia of Australian plants, suitable for cultivation, vol 3. Lothian Publishing Company, Melbourne

Etienne M, Michea G, Díaz E (1982) Flora, vegetación y potencial pastoral de la Isla de Pascua. Boletín Técnico $n^{\circ} 47$. Universidad de Chile, Facultad de Ciencias Agrarias, Veterinarias y Forestales, Santiago

Flenley JR (1993a) The palaeoecology of Easter Island, and its ecological disaster. In: Fischer SR (ed) Easter Island studies: Contribution to the history of Rapa Nui in memory of T Mulloy. The Short Run Press, Exeter, pp 27-45

Flenley JR (1993b) The present flora of Easter Island and its origins. In: Fischer SR (ed) Easter Island studies: contribution to the history of Rapa Nui in memory of T. Mulloy. The Short Run Press, Exeter, pp 7-15

Flenley JR (1996) Further evidence of vegetational change on Easter Island. South Pac Study 16:135-141

Flenley JR, Bahn P (2003) The Enigmas of Easter Island. Island on the Edge. University Press, Oxford

Flenley JR, King ASM, Jackson J, Chew C (1991) The late Quaternary vegetational and climatic history of Easter Island. J Quat Sci 6:85-115

Florence J, Chevillotte H, Ollier C, Meyer J-Y (2007) Base de données botaniques Nadeaud de l'Herbier de la Polynésie française (PAP). http://www.herbier-tahiti.pf

Franklin J, Keppel G, Whistler WA (2008) The vegetation and flora of Lakeba, Nayau and Aiwa Islands, Central Lau Group, Fiji. Micronesica 40:169-225

George AS (Executive editor) (1987) Flora of Australia, vol. 45. Hydatellaceae to Liliaceae. Australian Government Publishing Service, Canberra

George AS (Executive editor) (1994) Flora of Australia, vol. 49. Oceanic Islands Australian Government Publishing Service, Canberra

Herrera C, Custodio E (2008) Conceptual hydrogeological model of volcanic Easter Island (Chile) after chemical and isotopic surveys. Hydrogeol J 16:1,329-1,348

Hong YT, Wang ZG, Jiang HB, Lin QH, Hong B, Zhu YX, Wang Y, Xu LS, Leng XT, Li HD (2001) A 6000-year record of changes in drought and precipitation in northeastern China based on a $\delta^{13} \mathrm{C}$ time series from peat cellulose. Earth Planet Sci Lett 185:111-119

Horrocks M, Wozniak JA (2008) Plant microfossil analysis reveals disturbed forest and mixed-crop, dryland production system at Te Niu, Easter Island. J Archaeol Sci 35:126-142

Hunt T (2007) Rethinking Easter Island's ecological catastrophe. J Archaeol Sci 34:485-502 
Hunter JT, Bell D (2007) Vegetation of montane bogs in East-flowing catchments of Northern New England, New South Wales. Cunninghamia 10:77-92

Jenny B, Valero-Garcés BL, Villa-Martínez R, Urrutia R, Geyh M, Veit $\mathrm{H}$ (2002) Early to mid-Holocene aridity in central Chile and the southern westerlies: The Laguna Aculeo Record $\left(34^{\circ} \mathrm{S}\right)$. Quat Res 58:160-170

Kaiser J, Schefuß E, Lamy F, Mohtadi M, Hebbeln D (2008) Glacial to Holocene changes in sea surface temperature and coastal vegetation in north central Chile: high versus low latitude forcing. Quat Sci Rev 27:2,064-2,075

Maldonado A, Villagrán C (2006) Climate variability over the last 9900 cal. yr B.P. from a swamp forest pollen record along the semiarid coast of Chile. Quat Res 66:246-258

Mann D, Edwards J, Chase J, Beck W, Reanier R, Mass M, Finney B, Loret J (2008) Drought, vegetation change, and human history on Rapa Nui (Isla de Pascua, Easter Island). Quat Res 69:16-28

Margalef O, Cañellas-Boltà N, Pla-Rabes S, Giralt S, Pueyo JJ, Jooster H, Rull V, Buchaca T, Hernández A, Valero-Garcés BL, Moreno A, Sáez A (2013) A 70,000 year multiproxy record of climatic and environmental change from Rano Aroi peatland (Easter Island). Glob Planet Change. doi:10.1016/j.gloplacha. 2013.05.016

Maunder M, Culham A, Alden B, Zizka G, Orliac C, Lobin W, Bordeu A, Ramírez JM, Glissmann-Gough S (2000) Conservation of the Toromiro tree, case study in the management of a plant extinct in the wild. Conserv Biol 14:1,341-1,350

Moore LB, Edgar E (1970) Flora of New Zealand, volume II: Indigenous Tracheophyta: Monocotyledons except Graminae. Botany Division, Department of Scientific and Industrial Research, Christchurch

Orliac C (2000) The woody vegetation of Easter Island between the early 14th and the mid-17th centuries A.D. In: Stevenson CM, Ayres WS (eds) Easter Island archaeology. Research on early Rapanui Culture. Easter Island Foundation, Los Osos, pp 211-220

Orliac C, Orliac M (1998) The disappearance of Easter Island's forest, over-exploitation or climatic catastrophe? In: Stevenson CM, Lee G, Morin FJ (eds) Easter Island in Pacific context, South Seas symposium: proceedings of the fourth international conference on Easter Island and East Polynesia, Los Osos, pp 129-134
Paulay G, Spencer T (1989) Vegetation of Henderson Island. Atoll Res Bull 328:1-19

Prebble M, Wilmshurst JM (2009) Detecting the initial impact of humans and introduced species on island environments in Remote Oceania using palaeoecology. Biol Invasions $11: 1,529-1,556$

Rull V, Cañellas-Boltà N, Sáez A, Giralt S, Pla S, Margalef O (2010a) Paleoecology of Easter Island: evidence and uncertainties. Earth Sci Rev 99:50-60

Rull V, Stansell ND, Montoya E, Bezada M, Abbott MB (2010b) Palynological signal of the Younger Dryas in tropical Venezuelan Andes. Quat Sci Rev 29:3,045-3,056

Sáez A, Valero-Garcés BL, Moreno A, Bao R, Pueyo JJ, GonzalezSamperiz P, Giralt S, Taberner C, Herrera C, Gibert RO (2007) Lacustrine sedimentation in active volcanic settings: the late Quaternary depositional evolution of Lake Chungará (northern Chile). Sedimentology 54:1,191-1,222

Sáez A, Valero-Garcés BL, Giralt S, Moreno A, Bao R, Pueyo JJ, Hernández A, Casas D (2009) Glacial to Holocene climate changes in the SE Pacific. The Raraku Lake sedimentary record (Easter Island, $27^{\circ} \mathrm{S}$ ). Quat Sci Rev 28:2,743-2,759

Skottsberg C (ed) (1956) The natural history of Juan Fernández and Easter Island. Almquist \& Wiksells, Uppsala

Smith AC (1979) Flora Vitiensis Nova. A new Flora of Fiji (spermatophytes only), vol 1. Pacific Tropical Botanical Garden, Lawai

Valero-Garcés BL, Jenny B, Rondanelli M, Delgado-Huertas A, Burns SJ, Veit H, Moreno A (2005) Palaeohydrology of Laguna de Tagua Tagua $\left(34^{\circ} 30^{\prime} \mathrm{S}\right)$ and moisture fluctuations in Central Chile for the last 46,000 year. J Quat Sci 20:625-641

Waldren S, Florence J, Chepstow-Lusty AJ (1995) Rare and endemic vascular plants of the Pitcairn Islands, South-Central Pacific Ocean: a conservation appraisal. Biol Conserv 74:83-98

Wardle P (1991) Vegetation of New Zealand, vol 1. New Zealand, plants. Cambridge University Press, Cambridge

WCSP (2012) World Checklist of Selected Plant Families. Facilitated by the Royal Botanic Gardens, Kew. http://apps.kew.org/wcsp/, Accessed Oct 2012

Zizka G (1991) Flowering plants of Easter Island. Palmarum Hortus Francofurtensis Scientific Reports 3. Palmengarten, Frankfurt a. M

\begin{tabular}{|l|lll|}
\hline Journal : Large 334 & Dispatch : 19-1-2014 & Pages : $\mathbf{8}$ \\
Article No. : 432 & $\square$ LE & $\square$ TYPESET \\
MS Code : VHAA-D-13-00041 & $\sim_{\text {CP }}$ & $\checkmark$ DISK \\
\hline
\end{tabular}

